7. Reprod. Fertil. (1964) 8, 251-253

BRIEF COMMUNICATION

\title{
SIALIC ACID AS A COMPONENT OF THE ZONA PELLUCIDA OF THE MAMMALIAN OVUM
}

\author{
PIERRE SOUPART AND ROBERT W. NOYES
}

\author{
Department of Obstretics and Gynecology, \\ Vanderbilt University School of Medicine, Nashville, Tennessee, U.S.A.
}

(Received 14th April 1964)

This is one of several studies carried out in our laboratory, on the hypothesis that penetration of the zona pellucida by the spermatozoon may involve sialic acid residues ( $\mathrm{N}$-acetyl, $\mathrm{N}$-glycolyl, $\mathrm{N}, \mathrm{O}$-diacetyl, $\mathrm{N}$-acetyl-O-diacetyl-neuraminic acids).

Data from the literature suggest that the material constituting the zona is a conjugated protein. It is dissolved by several proteolytic enzymes (review by Austin, 1961 ; Gwatkin, 1963, 1964) and reacts positively with some carbohydrate reagents (Da Silva Sasso, 1959). Structural studies on glyco- or mucoproteins have shown sialic acid residues to be terminal units of carbohydrate prosthetic groups, of variable complexity, linked to a protein (Gottschalk, 1952). As few as one or two or as many as eight hundred sialic acid residues may be attached to a glycoprotein molecule (Gottschalk, 1962). Among the known glycoproteins, some, such as the gonadotrophic hormones and the hormone erythropoietin, depend on their constituent sialic acid residues for their biological activity. This activity is drastically reduced when the functional groups are split off by the specific enzyme neuraminidase (Whitten, 1948; Gottschalk, 1957; Lowy, Keighley \& Borsook, 1959; Gottschalk, Whitten \& Graham, 1960; Got \& Bourrillon, 1961). Sialic acid residues are also instrumental in the agglutination of red blood cells by heat-inactivated influenza virus (Burnet, $1948 \mathrm{a}, \mathrm{b})$. The meningoencephalitis virus, the particles of which are undoubtedly too large to diffuse through the zona, which is permeable only to substances of rather low molecular weight (Austin \& Lovelock, 1958), has nevertheless been observed to block development of two-cell mouse ova in vitro (Gwatkin, 1963). This suggests to us that the virus may penetrate the zona pellucida by an active mechanism possibly involving sialic acid residues and the specific enzyme neuraminidase (Gottschalk, 1959).

The present experiments were designed to demonstrate by histochemical methods the presence of sialic acid in the zona pellucida of several mammals. Since the sialic acid residues contain a free, strongly dissociated carboxyl group able to bind ferric ions in strongly acid solution ( $\mathrm{pH} 1 \cdot 1$ to $1 \cdot 3)$, use was made of the Hale's Method (Hale, 1946) for acid mucopolysaccharides as modified by Mowry (1958), in conjunction with treatment by a neuraminidase preparation (Vibrio Cholerae filtrate, Sigma Chemicals Co, St. Louis, Mo.). Serial sections 
of ovaries frozen and sectioned in the cryostat were stained by the above method, alternate sections being previously incubated overnight at $37^{\circ} \mathrm{C}$ with neuraminidase. In follicles from man, rhesus monkey, cow, dog, rabbit, golden hamster and guinea-pig the untreated sections stained a brilliant blue at the location of the zona pellucida (PI. 1, Fig. 1). This stain did not appear in control sections that were not exposed to iron, or in sections pretreated with neuraminidase (Pl. 1, Fig. 2), but it did appear in sections pretreated with heat-inactivated neuraminidase. The theca and connective tissue stained blue, indicating strongly acidic groups in their composition, but pretreatment with neuraminidase did not prevent staining as it did with the zona pellucida. Staining of all these structures was not affected by pretreatment with hyaluronidase. In sections of ovaries the zona of the rat and mouse failed to stain with the above method. In all sections the counter stain was haematoxylin-picric acid (Mowry, 1958).

Superovulated rat and mouse ova were prepared for electron microscopy using a method based on the techniques of Swift \& Adams (1962) and Gasic \& Berwick (1963) with special adaptation for the handling of isolated ova (P. Soupart, unpublished data, 1964). Under low magnification the zonae showed high electron density (Pl. 1, Fig. 3), and higher magnification disclosed this density to be due to cubic crystals characteristic of a ferric-ferrocyanide complex (Pl. 1, Fig. 4), similar to those observed when ferritin is treated by the same procedure (Thiery, 1962). Pretreatment with neuraminidase gave equivocal results with whole ova, possibly because neuraminidase can act only on surface sialic acid residues. The molecular weight of neuraminidase, about 90,000 (Laver, Pye \& Ada, 1964) is probably sufficient to prevent penetration of the enzyme into deeper layers of the zona.

Whether or not pretreatment by neuraminidase will inhibit the passage of spermatozoa through the zona is being studied by transferring ova pretreated in vitro into the oviducts of previously mated recipient animals. The present study gives evidence that sialic acid residues are abundant in the zonae pellucidae of man, cow, rhesus monkey, dog, rabbit, golden hamster and guinea-pig. Smaller amounts may be present in the rat and the mouse.

This work was aided by grants from the Association for the Aid to Crippled Children, the Ford Foundation, the National Foundation, and the U.S. Public Health Service (HD-00673-02).

\section{REFERENCES}

Austin, C. R. (1961) The mammalian egg, p. 90. Blackwell Scientific Publications, Oxford.

Austin, C. R. \& Lovelock, J. E. (1958) Permeability of rabbit, rat and hamster egg membranes. Exp. Cell Res. 15, 260.

Burnet, F. M. (1948a) The initiation of cellular infection by influenza and related viruses. Lancet, i, 7.

BURNET, F. M. (1948b) Mucins and mucoids in relation to influenza virus action. III. Inhibition of virus haemagglutination by glandular mucins. Aust. F. exp. Biol.med. Sci. $26,371$.

Da Silva Sasso, W. (1959) Existence of hyaluronic acid at the zona pellucida of the rabbit's ovum. Acta anat. 36, 352.

Gasic, G. \& BERwick, L. (1963) Hale stain for sialic acid-containing mucins. Adaptation for electron microscopy. J. cell. Biol. 19, 223.

Gor, R. \& Bourillon, R. (1961) Enzymic release of sialic acid and inactivation of human menopausal gonadotropin. Nature, Lond. 189, 234. 


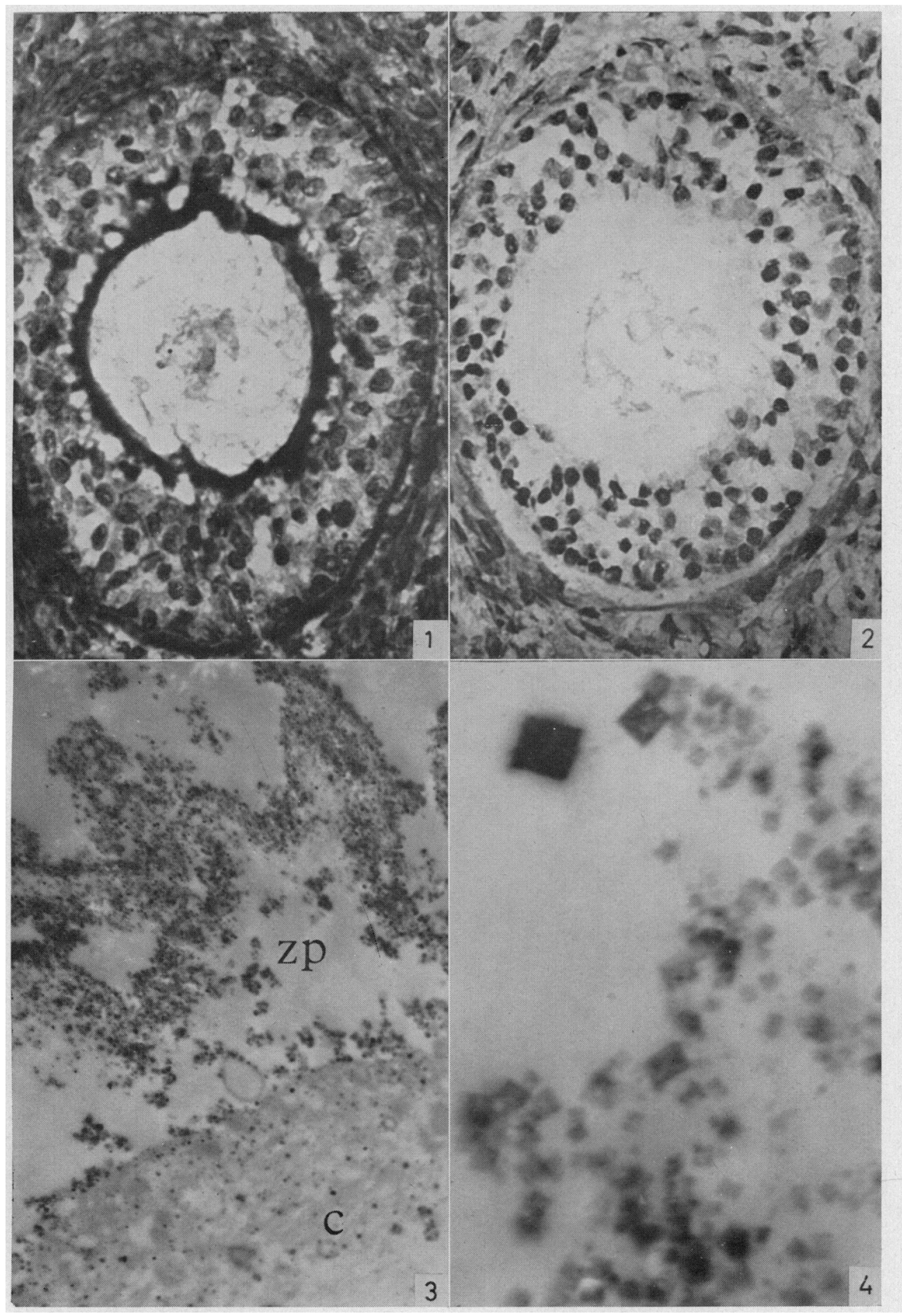

(Facing p). 252) 
Gotrschalk, A. (1952) Carbohydrate residue of a urine mucoprotein inhibiting influenza virus haemagglutination. Nature, Lond. 170, 662.

Gotrschalk, A. (1957) Neuraminidase: the specific enzyme of influenza virus and Vibrio cholerae. Biochim. biophys. Acta, 23, 645 .

Gorrschalk, A. (1959) On the mechanism underlying initiation of influenza virus infection. Ergebn. Mikrobiol. Immun.Forsch. 32, 1.

Gottschalk, A. (1962) The relation between structure and function in some glycoproteins. Perspect. Biol. Med. 5, 327.

Gottschalk, A., Whitten, W. K. \& Graham, E. R. B. (1960) Inactivation of follicle-stimulating hormone by enzymic release of sialic acid. Biochim. biophys. Acta, 38, 183.

Gwatkin, R. B. L. (1963) Studies on the zona pellucida of the mouse egg. F. Reprod. Fertil.6, 325.

Gwatkin, R. B. L. (1964) Effects of enzymes and acidity on the zona pellucida of the mouse egg before and after fertilization. 7 . Reprod. Fertil. 7, 99.

Hale, C. W. (1946) Histochemical demonstration of acid mucopolysaccharides in animal tissues. Nature, Lond. 157, 802.

Laver, W. A., Pye, J. \& AdA, G. L. (1964) The molecular size of neuraminidase from Vibrio cholerae (strain 4Z). Biochim. biophys. Acta, 81, 177.

Lowy, P. H., Keighley, A. \& Borsook, H. (1959) Inactivation of erythropoietin by neuraminidase and by mild substitution reactions. Nature, Lond. 185, 102.

Mowry, R. W. (1958) Improved procedure for the staining of acidic polysaccharides by Müller's colloidal (hydrous) ferric oxide and its combination with the Feulgen and the periodic acidSchiff reactions. Lab. Invest. 7, 566.

SwiFt, H. \& ADAms, B. J. (1962) Simple methods for nucleic acid and mucopolysaccharide localization in electron micrographs. Electron Microscopy, p. O-1. Ed. S. S. Breese, Jr. Academic Press, New York.

ThIERy, J. P. (1962) Étude des réactions cytochimiques du fer au microscope électronique. Electron Microscopy, p. L-9. Ed. S. S. Breese, Jr. Academic Press, New York.

WhITTEN, W. K. (1948) Inactivation of gonadotrophins. II. Inactivation of pituitary and chorionic gonadotrophins by influenza virus and receptor-destroying enzyme. Aust. $\mathcal{J}$. sci. Res. B, 1, 388.

\section{EXPLANATION OF PLATE 1}

Fig. 1. Human follicle, Hale's stain. Note the deep staining of zona pellucida and the sharp and denser line of the vitelline membrane. $\times 500$.

Frg. 2. Human follicle, Hale's stain after incubation with neuraminidase. Neither the zona nor the vitelline membrane are stained. $\times 500$.

FIG. 3. Electron micrograph of rat ovum. Hale's method. Note high electron density in the zona pellucida (zp) and some spots of similar density scattered through the cytoplasm (c). $\times 12,000$.

Frg. 4. Electron micrograph of zona pellucida, rat ovum, Hale's method. Note cubic crystals characteristic of ferric-ferrocyanide complex. $\times 80,000$. 